\title{
Novel genetic findings
}

\author{
Axel Bohring \\ From 5th International Conference on Ectodermal Dysplasia (ED2012) \\ Erlangen, Germany. 1-3 June 2012
}

Here we report on the clinical findings and key symptoms in WNT10A-related ectodermal dysplasias. The ectodermal dysplasias (ED) are a large, heterogeneous group of disorders characterized by defects in the morphogenesis of skin, sweat, sebaceous, submucous, and mammary glands, hair, nails and teeth. Numerous more or less distinct entities have been reported, however, most of them are very rare and the cause is often unknown. EDA mutations, resulting in hypohidrotic ectodermal dysplasia (Christ Siemens Touraine syndrome) are known as the most common cause of ED. Over the last two years, WNT10A has turned out to be the second major gene associated with ED. WNT10A mutation carriers present with a broad and variable spectrum of symptoms related to at least four known Mendelian conditions as there are autosomal dominant Selective Tooth Agenesis Type 4 and autosomal recessive Adontia of Permanent Dentition (APD), OdontoOnycho-Dermal Dysplasia (OODD), and Schöpf-SchulzPassarge syndrome (SSPS). In heterozygotes, penetrance is reduced and only about half of the carriers show a phenotype including mainly tooth and nail anomalies. Approximately $8 \%$ of the unaffected individuals in our control group carried a WNT10A mutation. Further studies are necessary. We conclude that WNT10A mutation analysis might become an important diagnostic test in many patients with selective tooth agenesis or severe oligodontia concerning the permanent teeth.

Published: 25 May 2012

doi:10.1186/1746-160X-8-S1-I10

Cite this article as: Bohring: Novel genetic findings. Head \& Face Medicine 2012 8(Suppl 1):110.

Submit your next manuscript to BioMed Central and take full advantage of:

- Convenient online submission

- Thorough peer review

- No space constraints or color figure charges

- Immediate publication on acceptance

- Inclusion in PubMed, CAS, Scopus and Google Scholar

- Research which is freely available for redistribution 